ISSN 1818-1295 eISSN 2616-6194

REPORTS OF MORPHOLOGY
$\begin{gathered}\text { Official Journal of the Scientific Society of Anatomists, } \\ \text { Histologists, Embryologists and Topographic Anatomists } \\ \text { of Ukraine } \\ \text { journal homepage: https://morphology-journal.com }\end{gathered}$

\title{
Comparative anatomy of the uterine tube of human and laboratory white rat females
}

\author{
Podolyuk M.V. \\ Danylo Halytskyy National Medical University of Lviv, Lviv, Ukraine
}

\section{ARTICLE INFO}

Received: 4 October, 2018

Accepted: 6 November, 2018

UDC: $611.656-019$

CORRESPONDING AUTHOR

e-mail: Ivatseba@gmail.com Podolyuk M.V.
The world literature has accumulated a considerable amount of data to characterize the main components of the female genital system, functional relationships between them, as well as the links between this system and other systems of the organism. The relevance of the study is also due to the fact that in the structure of female infertility 60$70 \%$ is occupied by a tubo-peritoneal factor. The problems associated with this pathology have been studied for more than half a century. Until now, information about the microanatomy of the fallopian tube of a human and, especially, of the female white laboratory rat is contradictory. The aim of the study was to conduct a comparative analysis of the structural organization of the uterine tube of a human and female laboratory white rat. The article and analyzes the data of research conducted on 10 sexually mature white rats in females of reproductive age. The method of preparation was used, for the study of macroanatomy of the uterine tube of females, and also standard histological methods (cuts of the wall of the fallopian tube in the thickness of 5-7 microns, stained with hematoxylin and eosin). The external structure of the fallopian tube of the female rat and man has some differences. Unlike humans, the fallopian tube of a white laboratory rat has the appearance of a thin and short tubule, spirally twisted into a compact lump. In the fallopian tube of the female white rat, it is advisable to distinguish 2 parts: the funnel and the fallopian part. The uterine part connects to the uterine horn cavity of the uterine opening of the fallopian tube, and the fallopian tube opens into the cavity of the peritoneum to the surface of the ovary by the abdominal opening of the fallopian tube. Around the funnel of the fallopian tube, its mucous membrane is gathered in folds - the fringe of the fallopian tube and the ovarian fringe (in humans - one ovarian fringe), which are attached to the ovary. The diameter of the fallopian tube of the female white rat decreases in the direction from the funnel to the uterine part. In particular, in the area of the funnel, the diameter of the fallopian tube is $0.90 \pm 0.10 \mathrm{~mm}$, and the diameter of the fallopian part is $0.70 \pm 0.09 \mathrm{~mm}$. The uterine tube of a laboratory white rat, like a human, has a mesentery of the fallopian tube. Both in human and in female white rat, the wall of the fallopian tube consists of three layers: the inner lining is mucous, the middle lining is muscular, the outer lining is serous. It was established that the female uterine tube of a white rat in its macroscopic structure differs from the uterine tube of a person. The microscopic structure of human and the white rat female uterine tube is rather similar and, therefore, may serve as an object of the experimental modeling of certain pathological conditions of the reproductive system. Keywords: reproductive system, uterine tube, white rat.

\section{Introduction}

The female sexual system is an integral part of a complex biological system - the body as a whole [11, 21]. In world literature, a significant amount of data has been accumulated to characterize the main components of the female genital system, functional relationships between them, and the relationships between this system and other systems of the body [2]. The female reproductive system is a complex biological phenomenon, through which nature implements a program of preservation and extension of the genus. The fallopian tube is considered a sterile organ, in which the final maturation of the gametes, fertilization and early development of the embryo occurs [23]. 
One of the most urgent problems of gynecology is female infertility in the structure of which $60-70 \%$ occupies tube-peritoneal factor. Despite significant advances in reproductive medicine, the problems of diagnosis and treatment of tubal peritoneal infertility remain relevant. Acute and chronic inflammatory diseases of the fallopian tubes, operative interference on the pelvic organs, infection of the genital tract, autoimmune, and tumor processes have the leading place among the factors of the formation of the tube-peritoneal factor. In addition, there are reports in the literature that the secretory cells of the uterine mucosa are the source of ovarian carcinoma [13]. Pathological processes in the fallopian tube can be the cause of ectopic pregnancy. Problems associated with this pathology have been studied for more than half a century [18, 20, 24]. The evaluation of macro- and microanatomy of the fallopian tubes remains an important test in the examination of infertile couples, as well as in the definition of treatment approaches. Despite the many published scientific papers on the mechanisms of development of the tubal-peritoneal factor, numerous etiological factors and clinical aspects remain open. An analysis of the current trends in the study of the structure and function of the fallopian tube shows that the issue of a comprehensive approach to the morphofunctional justification for assessing the state of a given organ under conditions of physiological norm and pathology remains inadequately studied.

The purpose of our study was to conduct a comparative analysis of the structural organization of the uterine tube of a human and laboratory white rat.

\section{Materials and methods}

The study was performed on 10 sexually mature white rats of reproductive age (10 females) weighing 180-200 g. As a research material, wet macroscopic preparations of human uterine tube from the Fund of the Department of Normal Anatomy of the Danylo Halytskyy National Medical University of Lviv were also used. The method of preparation for the study of macroanatomy of the uterine tube of female white rats, as well as standard histological methods (sections of the wall of the fallopian tube in the thickness of 5-7 microns, stained with hematoxylin and eosin) were used to study the microanatomy of the wall of the uterine tube of a white rat and a human. Images from the histologic preparations of the uterine wall on the computer monitor were taken from a microscope MICROmed SEO SCAN and with a Vision CCD Camera.

All experimental animals were kept under the vivarium of the Danylo Halytskyy National Medical University of Lviv. The research was conducted in accordance with the provisions of the "European Convention for the Protection of Vertebrate Animals used for Experimental and Other Scientific Purposes" (Strasbourg, 1986), Council of Europe Directives 86/609/EEC (1986), Law of Ukraine No. 3447-IV "On the Protection of Animals from ill-treatment", the general ethical principles of experiments on animals adopted by the First National Congress of Ukraine on Bioethics (2001). Euthanasia of animals was performed by overdose of intraperitoneal anesthesia using sodium thiopental (at a rate of $25 \mathrm{mg} / \mathrm{kg}$ body weight of the animal).

\section{Results}

The fallopian tube of a laboratory white rat, like the human's fallopian tube, is a paired hollow organ. Located in the cavity of a small pelvis, almost horizontally, near the upper edge of a broad ligament of the uterus. The outer structure of the rats and humans fallopian tube has some differences. The female tube has a cylindrical shape, 4 parts: the interstitial (pars uterina), which passes through the wall of the uterus and opens into the uterus cavity as uterine tube (ostium uterinum tubae uterinae); isthmus of uterine tube (isthmus tubae uterinae), which is closest to the uterus; ampulla of uterine tube (ampulla tubae uterinae) - the largest part of the fallopian tubes; fimbria of fallopian tubes (infundibulum tubae uterinae) - an enlarged part that opens as the abdominal hole of the fallopian tube (ostium abdominale tubae uterinae) into the abdominal cavity and is surrounded by fimbriae (fimbria tubaria), one of which is the fimbria ovarica, longer than the other, while its diameter decreases from the fimbria $(2-4 \mathrm{~mm})$ to the uterine part (1 $\mathrm{mm}$ ).

The fallopian tube of a laboratory white rat has the form of a thin and short tube, twisted spirally into a compact glomeruli (Fig. 1A, 1B). In our opinion, it is advisable to distinguish 3 parts in the uterine tube of rats: fimbria, middle (spiral) and uterine part. The uterine part is connected to the uterine horn cavity by the uterine hole of uterine tube (ostium uterinum tubae uterinae), and the fimbria (infundibulum tubae uterinae) is opened in the peritoneal cavity to the ovary surface by the abdominal hole of tube (ostium abdominale tubae uterinae).

Around the fimbria of the uterine tube, its mucosa is collected in folds - the fimbriae of the uterine tube and the ovary fimbriae (in humans, as already mentioned above, one ovary fimbriae), which are attached to the ovary. In this case, the diameter of the uterine tube of the white rat also decreases in the direction from the fimbria to the uterine part. In particular, in the area of the fimbria, the diameter of the uterine tube is $0.90 \pm 0.10 \mathrm{~mm}$, and the diameter of the uterine part is $0.70 \pm 0.09 \mathrm{~mm}$. The fallopian tube, in laboratory white rat, like in human, has mesosalpinx. As in human, uterus tube wall in rats consists of three layers: the inner - mucosa, the middle - subserosa, and the outer membrane - serosa (Fig. 2).

The mucosa of the fallopian tubes of white rat forms branched longitudinal and transverse folds that thicken towards the abdomen part of the fallopian tube. The mucosa is covered by a simple columnar epithelium consisting of ciliated cells and peg cells. The epithelium is located on a thin basal membrane, under which lies amina propria, formed by a loose connective tissue. The muscular plate of the mucous membrane and the submucosal base in 

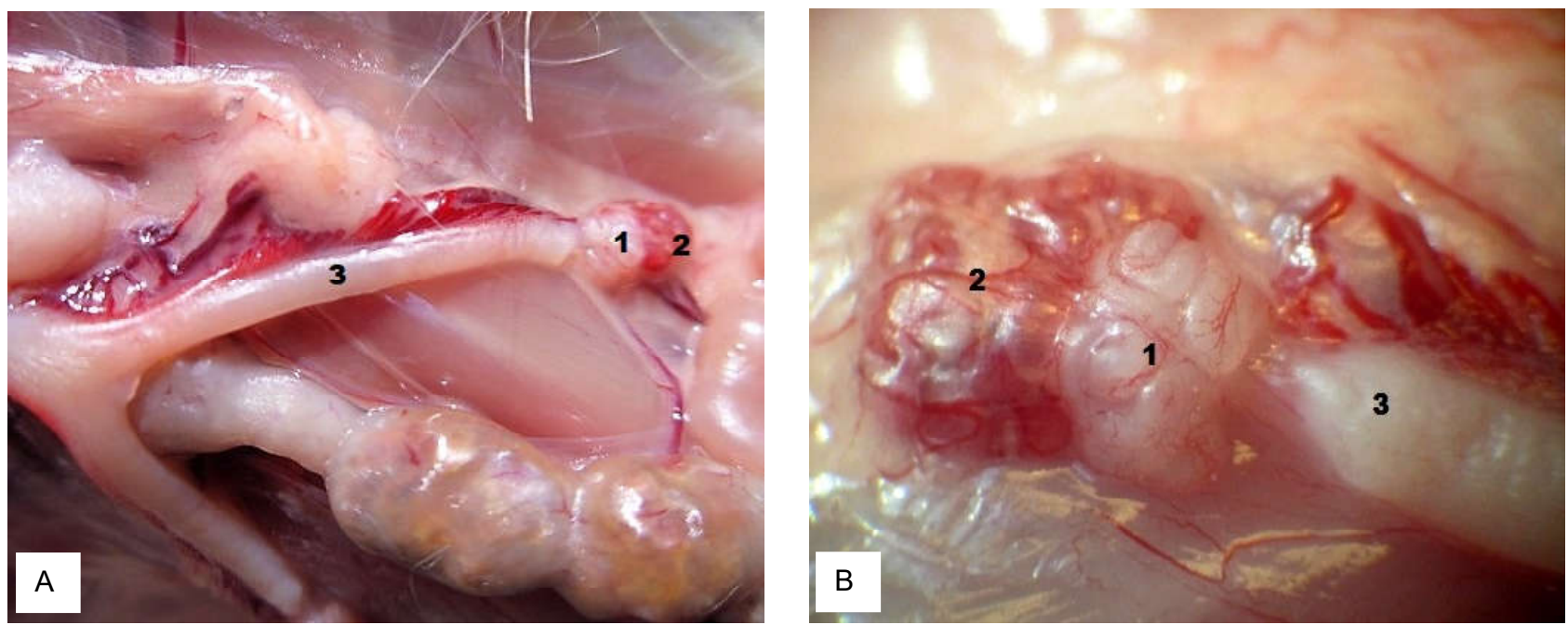

Fig. 1. A - Uterine tube of white rat in norm. Photomacrograph. 1 - uterine tube, 2 - ovary, 3 - uterine horn; B - Uterine tube of white rat in norm. Photomacrograph (binocular enlargement). 1 - uterine tube, 2 - ovary, 3 - uterine horn.

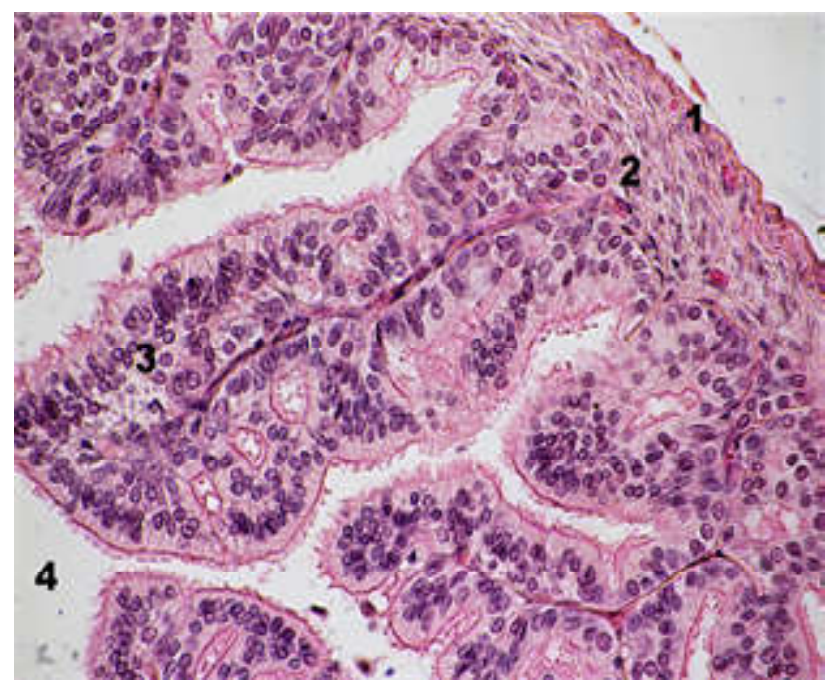

Fig. 2. Uterine tube wall of white rat in norm. Hematoxylin-eosin. Photomicrograph. x400. 1 - serosa, 2 - subserosa, 3 - mucosa, 4 - fallopian tube lumen.

the uterine tube are absent, so the connective tissue of the own plate directly passes into the muscle skeleton. It should be noted that the mucous membrane of the uterine tube along with the endometrium undergoes cyclic changes during the menstrual cycle, during pregnancy, and during puberty. In addition, the mucosa of the uterine tube does not contain glands, and this function is performed by the peg cells, functioning of which is regulated by the endocrine system. In laboratory white rats, subserosa consists of an internal circular and outer longitudinal layers, which passes into the myometrium of the uterine horn. Due to the peristaltic contraction of smooth myocytes and the movement of cilia, the egg cell moves along the fallopian tube towards the uterus. In humans, subserosa also consists of the inner circular and outer longitudinal layers. Externally, the uterine tube is covered with a serosa.

\section{Discussion}

The blood supply to the fallopian tubes is carried out from two sources: tubal branches of ovarian artery and tubal branch of uterine artery. Venous blood from the uterine tube flows out on the veins of the same name. Lymphatic vessels of the tube enter the lumbar lymph nodes. However, in literary sources, there are data on the autonomic blood supply ampulla and isthmus of the uterine tube [3, 12]. In the literature on the structure of the human uterine tube, there are data that in the ampule and the fimbria of the uterine tube on the longitudinal folds of the mucosa there are secondary, which, in turn, may appear tertiary folds [1, 14]. However, in the mucosa of the white rats uterine tube we did not detect of secondary and tertiary folds. The role of cilia is most pronounced in the ampulla of the uterine tube, where the thickness of the subserosa is up to five times smaller than the isthmus $[6,13]$. According to many authors, the contraction of the subserosa help to captures the egg by fimbriae $[2,4,19]$. Other authors believe that the frequency of cilia movement influences the speed of movement of the egg and the embryo [8, 16, 22]. In addition, we have investigated that the number of epithelial cells of the mucosa of the uterine tube (secretory, basal, ciliated) is not the same throughout the length of the uterine tube of both human and white rats. The largest number of cilia in the fimbriae and ampulla gradually decreases in the direction of the uterus, and the secretory cells are the smallest in the fimbriae and ampulla, and most in the uterine part, which is consistent with the literature [2, 25]. As for the structure of the subserosa, there are also several thoughts. Some authors believe that there are outer longitudinal and inner circular smooth muscle coats [5], while others - distinguish three layers: the weakly developed outer longitudinal layer, the middle - circular, and internal longitudinal, which is particularly well developed in the uterine part of the tube $[16,17]$. In addition, there are data 
that in the area of the isthmus of the fallopian tube, the subserosa has an additional inner longitudinal layer in which smooth myocytes are located obliquely spirally [1, 7]. There is no clear boundary between the longitudinal and circular layers. Thus, the muscular stratum is less pronounced in the fimbria of the uterine tube than in the isthmus, in which the inner layers of smooth myocytes have the greatest development and form the muscle of the uterine tube $[9,15]$.

The serosa of the fallopian tubes, both human and white rat, consists of six layers: mesothelium, basement membrane, surface fibrous collagen layer, surface elastic mesh, deep elastic mesh, lattice collagen layer. It is precisely this structure that allows one body parts to lengthen, while others reduce and this allows the lumen of the uterine tube to increase, without simultaneously increasing its length. The results of our histological studies of the fallopian tubes of white rats allowed us to establish the following patterns: on the outside, the uterine tube is covered with a thin serosa, consisting of a single layer of mesothelial cells lying on a thin connective tissue basement

\section{References}

[1]Adamyan, L. V., Kharchenko, E. I., Bragina, E. E., Murvatov, K. D., Stepanyan A. A., \& Zobova A. V. (2015). Epithelium structure of the fimbrial branch of the fallopian tubes in women of reproductive age. Reproduction Problems, 21(4), 8-16.

[2] Aketayeva A. (2016). Modern view on the anatomy and function of the fallopian tubes. Clinical medicine of Kazakhstan, 40(2), 14-21. doi:10.23950/1812-2892-2016-2-14-21.

[3] Akhmedova, M. I., Khozhanazarova, S. Zh., Ashurova, F. K., \& Mardonov, B. R. (2016). Morphological characteristics of intraorgan tubal vessels in experimental diabetes mellitus. Journal of Theoretical and Clinical Medicine, 1, 9-11.

[4] Asaturova. A. V, Ezhova, L. S, Fayzullina, N. M., Adamyan, L. V, Habas, G. N., \& Sannikova, M. V. (2017). Expansion of secretory cells of the uterine tube epithelium in the early stages of pathogenesis serous carcinoma of the ovary. Archive of pathology, 79(3), 10-18.

[5] Bakhmet, A. A., Kuznetsova, M. A., Miroshkin, D. V., \& Kupriyanov, I. E. (2015). Morphological structure of the mucous membrane of the ureter and fallopian tubes. Academic Journal of Western Siberia, 11(2), 141-142.

[6] Chen, H., Klein, R., Arnold, S., Chambers, S., \& Zheng, W. (2016). Cytologic studies of the fallopian tube in patients undergoing salpingo-oophorectomy. Cancer Cell. Int., 16, 78. DOI: 10.1186/s12935-016-0354-x.

[7] Col?n, E., \& Carlson, J. W. (2014). Evaluation of chemotherapy after persistence of the tube after neoadjuvant chemotherapy: persistence of serous tubal intraepithelial carcinoma. Int. J. Gynecol. Pathol. 33(5), 463-469. doi: 10.1097/ PGP.0b013e3182a142c.2.

[8] Deel, C. D., Allen, R. A., Holman, L. L., \& Zuna, R. E. (2016). Adenocarcinoma of the cervix involving the fallopian tube mucosa: report of a case. Diagn Pathol., 11, 77. doi: 10.1186/ s13000-016-0529-8.

[9] Dixon, D., Alison, R., Bach, U., Colman, K., Foley, G. L., Harleman, J. H. ... Yoshida M. (2014). Nonproliferative and Proliferative Lesions of the Rat and Mouse Female Reproductive System. J. Toxicol. Pathol. 27(3-4). 1S-107S. doi: 10.1293/tox.27.1S. membrane. Under the serous membrane is located an outer circular layer of the muscular membrane, under it the inner longitudinal. Between the subserosa and the mucosa of the fallopian tubes there is lamina propria. The mucosa of the uterine tube is structurally similar to the endometrium, the epithelium of the mucous membrane is cylindrical, represented predominantly by cilia.

The obtained results of the study may be useful in the modeling of diseases of the reproductive system, because it is necessary to take into account the features of the macro- and microstructure of the experimental animal in order to extrapolate experimental data to medical practice.

\section{Conclusions}

1. Uterine tube of white rats in their macroscopic structure different from human uterine tube.

2. The microscopic structure of the uterine tube of a human and white rat is quite similar, which allows it to be used as an object in the experimental modeling of the determination of pathological states of the reproductive system.

[10] Dzhadranov, E. S., Ibadullaeva, G. S., Yergazina, M. Zh., Krasnoshtanov, A. V., Krasnoshtanov, V. K., Kemelbekova, A. K., \& Zhusip, B. P. (2016). Structural features of some internal organs of the laboratory mice of reproductive age. Bulletin of KazNMU, 4, 266-269.

[11] Dzis, N. P. (2014). Before feeding on the reproductive function of women from a gynecologic pathology of the pilot and nonspontaneous genesis. Bulletin of Vinnitsa National Medical University, 18(1), 2, 302-306.

[12] Foti, P. V., Ognibene, N., Spadola, S., Caltabiano, R., Farina, R., Palmucci, S. ... Ettorre, G. C. (2016). Non-neoplastic diseases of the fallopian tube: MR imaging with emphasis on diffusionweighted imaging. Insights Imaging, 7(3), 311-327. doi: 10.1007/s13244-016-0484-7.

[13] Hua, G., Lv, X., He, C., Remmenga, S. W., Rodabough, K. J., Dong, J., \& Wang, C. (2016). YAP induces high-grade serous carcinoma in fallopian tube secretory epithelial cells. Oncogene, 35(17), 2247-2265. doi: 10.1038/onc.2015.288.

[14] Kessler, M., Fotopoulou, C., \& Meyer, T. (2013). The Molecular Fingerprint of High Grade Serous Ovarian Cancer Reflects Its Fallopian Tube Origin. International Journal of Molecular Sciences, 14(4), 6571-6596. doi: 10.3390 / ijms14046571.

[15] Kessler, M., Hoffmann, K., Brinkmann, V., Thieck, O., Jackisch, S., Toelle, B. ... Meyer, T. F. (2015). The Notch and Wnt pathways regulate stemness and differentiation in human fallopian tube organoids. Nat. Commun., 6, 8989. doi: 10.1038/ ncomms9989.

[16] Kharchenko, E. I., Adamyan, L. V., Bragina, E. E., Murvatov, K. D., Stepanyan, A. A., \& Arslanian, K. N. (2012). Ultrastructural study of tubal epithelium in women of reproductive age with benign tumors and ovarian cysts. Obstetrics and gynecology, 7, 50-53.

[17] Klyuchko, S. S., Yevtushenko, V., Sokolovskiy, D. M., \& Shilan, K. V. (2016). Morphological features of the lymphoid component of the sheath of the uterine tubes of the domestic market. Actual problems of medicine, 16-4 (56-2), 14-17.

[18] Lee, N. K., Choi, K. U., Han, G. J., Kwon, B. S., Song, Y. J., Suh, 
D. S., \& Kim K. H. (2016). Pseudocarcinomatous hyperplasia of the fallopian tube mimicking tubal cancer: a radiological and pathological diagnostic challenge. J. Ovarian Res., 9, 79. doi: 10.1186/s13048-016-0288-x.

[19] Matsumoto, H. (2017). Molecular and cellular events during blastocyst implantation in the receptive uterus: clues from mouse models. J. Reprod. Dev., 63(5), 445-454. doi: 10.1262/ jrd.2017-047.

[20] Niikura, R., Hayakawa, Y., Hirata, Y., Konishi, M., Suzuki, N., Ihara, S. ... Koike, K. (2018). Distinct Chemopreventive Effects of Aspirin in Diffuse and Intestinal-Type Gastric Cancer. Cancer Prev. Res., 11(4). doi: 10.1158/1940-6207.CAPR-17-0276.

[21] Sari, M. E., Ozdemir, O., Kadirogullari, P., Ertugrul, F. A., \& Atalay, C. R. (2015). Mature Cystic Teratoma of the Fallopian Tube in a Postmenopausal Woman: A Case Report and Review of the Literature. Case Rep. Obstet. Gynecol., 583021. doi: $10.1155 / 2015 / 583021$.

[22] Teijeiro, J. M., \& Marini, P. E. (2015). S100A7 in the Fallopian tube: a comparative study. Zygote, 23(2), 229-236. doi: $10.1017 /$ S0967199413000464.

[23] Voznesenska, T. Yu., Koleinkova, O. M., Blashkiv, T. V., Brizgina, T. M., Sukhina, V. S., \& Yanchiy, R. I. (2013). Functional organ of the reproductive system in the minds of the experimental ear-numbered stem from Misha. Visnyk problems biologiii $i$ medicine, 2(100), 125-128.

[24] Wang, C., Liu, Y., Chang, C., Wu, S., Gao, J., Zhang, Y. ... Deng, G. (2016). Human fallopian tube proteome shows high coverage of mesenchymal stem cells associated proteins. Biosci. Rep., 36(1). e00297. doi: 10.1042/BSR20150220.

[25] Yuan, J., Zhao, W., Yan, M., Zhu, Q., Qin, G., Qiu, J., Zhang, J. (2015). Ulipristal Acetate Antagonizes the Inhibitory Effect of Progesterone on Ciliary Beat Frequency and Upregulates Steroid Receptor Expression Levels in Human Fallopian Tubes. Reprod. Sci., 22(12), 1516-1523. doi: 10.1177/ 1933719115589409.

\section{ПОРІВНЯЛЬНА АНАТОМІЯ МАТКОВОЇ ТРУБИ ЛЮДИНИ ТА САМКИ ЛАБОРАТОРНОГО БІЛОГО ЩУРА \\ Подолюк М.В.}

У світовій літературі накопичено значний обсяг даних для характеристики основних компонентів жіночої статевої системи, функціональних взаємозв'язків між ними, а також зв'язків між цією системою та іншими системами організму. Актуальність дослідження зумовлена також тим, що в структурі жіночого безпліддя 60-70\% займає трубно-перитонеальний фрактор. Проблеми, пов'язані з иією патологією, вивчають понад півстоліття. На сьогоднішній день дані про мікроанатомію маткової труби людини, а, тим паче, самки білого щура є суперечливими. Метою дослідження було провести порівняльний аналіз структурної організації маткової труби людини і самки лабораторного білого щура. Дослідження проводили на 10 статевозрілих білих щурах самках репродуктивного віку. Застосовано метод препарування (для дослідження макроанатомії маткової труби самки білого щура) та стандартні гістологічні методи (зрізи стінки маткової труби товщиною 5-7 мкм, забарвлені гематоксиліном та еозином). Зовнішня будова маткової труби самки щура і людини має деякі відмінності. На відміну від людини, маткова труба лабораторного білого щура має вигляд тонкої і короткої трубочки, скрученої спірально у компактний клубочок. У матковій трубі самки білого щура доцільно розрізняти 2 частини: лійку і маткову частину. Маткова частина з'єднується з порожниною рогу матки матковим отвором маткової труби, а лійка маткової труби відкривається в порожнину очеревини до поверхні яєчника черевним отвором маткової труби. Навколо лійки маткової труби ї слизова оболонка зібрана в складки - торочки маткової труби та яєчникові торочки (у людини - одна яєчникова торочка), які кріпляться до яєчника. При цьому діаметр маткової труби самки білого щура зменшується в напрямку від

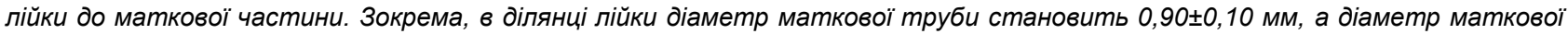

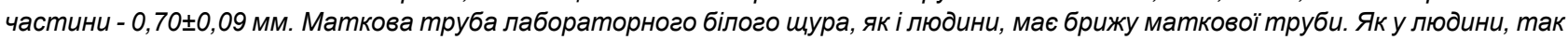
і в самки білого щура стінка маткової труби складається з трьох шарів: внутрішня оболонка - слизова, середня оболонка - м'язова, зовнішня оболонка - серозна. Таким чином, маткова труба самки білого шура за своєю макроскопічною будовою відрізняється від маткової труби людини. Мікроскопічна будова маткової труби людини і самки білого щура досить подібні, що дозволяє використовувати їі як об'єкт при експериментальному моделюванні певних патологічних станів репродуктивної системи.

Ключові слова: репродуктивна система, маткова труба, білий щур.

\section{СРАВНИТЕЛЬНАЯ АНАТОМИЯ МАТОЧНОЙ ТРУБЫ ЧЕЛОВЕКА И САМКИ ЛАБОРАТОРНОЙ БЕЛОЙ КРЫСЫ \\ Подолюк М.В.}

В мировой литературе накоплен значительный объем данных для характеристики основных компонентов женской половой системы, функциональных взаимосвязей между ними, а также связей между этой системой и другими системами организма. Актуальность исследования обусловлена тем, что в структуре женского бесплодия 60-70\% занимает трубноперитонеальный фрактор. Проблемы, связанные с этой патологией, изучают более полувека. До сих пор сведения о микроанатомии маточной трубы человека и, тем более, самки лабораторного белой крысы противоречивы. Целью исследования было провести сравнительный анализ структурной организации маточной трубы человека и самки лабораторной белой крысы. В статье приведены и проанализированы данные исследования, которые проводили на 10 половозрелых белых крысах-самках репродуктивного возраста. Для исследования макроанатомии маточной трубы самки белой крысы применили метод препарирования, а также стандартные гистологические методы (срезы стенки маточной трубы толщиной 5-7 мкм, окрашенные гематоксилином и эозином). Внешнее строение маточной трубы самки крысы и человека имеет некоторые отличия. В отличие от человека, маточная труба лабораторной белой крысы имеет вид тонкой и короткой трубочки, скрученной спирально в компактный клубочек. В маточной трубе самки белой крысы целесообразно различать 2 части: воронку и маточную часть. Маточная часть соединяется с полостью рога матки маточным отверстием маточной трубы, а воронка маточной трубы открывается в полость брюшины к поверхности яичника брюшным отверстием маточной трубы. Вокруг воронки маточной трубы ее слизистая оболочка собрана в складки - бахромки маточной трубы и яичниковые бахромки (у человека - одна яичниковая бахромка), которые крепятся к яичнику. 
При этом диаметр маточной трубы самки белой крысы уменьшается в направлении от воронки к маточной части. $B$

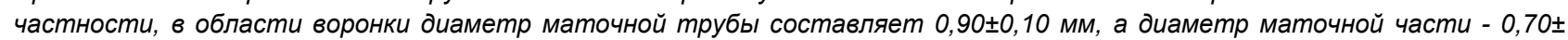
0,09 мм. Маточная труба лабораторной белой крысы, как и человека, имеет брыжейку маточной трубы. Как у человека, так и у самки белой крысы стенка маточной трубы состоит из трех слоев: внутренняя оболочка - слизистая, средняя оболочка - мышечная, внешняя оболочка - серозная. Таким образом, маточная труба самки белой крысы по своему макроскопическому строению отличается от маточной трубы человека. Микроскопическое строение маточной трубы человека и самки белой крысы достаточно похожи, что позволяет использовать ее как объект при экспериментальном моделировании определенных патологических состояний репродуктивной системы.

Ключевые слова: репродуктивная система, маточная труба, белая крыса. 